\title{
Gentianopsis paludosa var. alpina (Gentianaceae), a new record for India from Ladakh, Trans-Himalaya
}

\author{
Banoo S. ${ }^{1}$, Gulzar R. ${ }^{1}$, Islam T. ${ }^{1}$, Ganie A.H. ${ }^{2}$ \& A.A. Khuroo ${ }^{1 *}$ \\ ${ }^{1}$ Centre for Biodiversity \& Taxonomy, Department of Botany, University of Kashmir, Srinagar, J \& K - 190006 , India \\ ${ }^{2}$ Department of Botany, University of Kashmir, Kargil Campus, Ladakh - 194 103, India \\ *E-mail: anzarak@uok.edu.in
}

\begin{abstract}
Gentianopsis paludosa (Hook.f.) Ma var. alpina T.N.Ho. is reported as a new record for India from the Trans-Himalayan region of Ladakh, Union Territory in India. The identification is confirmed based on diagnostic characters, such as branching from the base, oblong to elliptic-lanceolate cauline leaves, 5-20 flowers per plant, up to $20 \mathrm{~cm}$ long pedicels and white to creamy yellow corolla. A detailed taxonomic description with coloured photographs of its diagnostic features is provided to facilitate easy field identification.
\end{abstract}

Keywords: Biodiversity, Taxonomy, Trans-Himalaya.

\section{Introduction}

World over, the family Gentianaceae comprises about 100 genera and 1800 species (Pringle, 2014). In India, the family is represented by c. 20 genera, including Gentianopsis Ma (Garg, 1988). Until 1951, Gentianopsis was placed within Gentianella Moench, but later on it was recognised as a separate genus (Ma, 1951; Iltis, 1965). Gentianopsis can be easily distinguished from Gentianella on the basis of floral characters such as flattened ellipsoidal flower buds, dissimilar pair of calyx, distinct gynophores and enlarged stigma (Ma, 1951). Globally, Gentianopsis comprises c. 22 species, mainly distributed in temperate regions of the northern Hemisphere (POWO, 2019). Several species of Gentianopsis possess medicinal properties and are used in Tibetan traditional medicine (Xue \& Li, 2011).

Received: 26.01.2021; Revised \& Accepted: 28.05.2021

Published Online: 30.06.2021
During recent botanical surveys conducted in the Trans-Himalayan region of Ladakh, the authors collected hitherto unreported specimens of Gentianopsis taxa in India. After detailed morphological investigation of the collected specimens with the help of the relevant literature (Ho \& Pringle, 1995), the specimens were identified as G. paludosa (Hook.f.) Ma var. alpina T.N.Ho, a taxon previously not discovered in this region, despite several floristic studies on the flora of the region (Gurmet, 2004; Chaurasia et al., 2008; Kala, 2011; Dvorsky et al., 2018; Dar \& Khuroo, 2020). The new variety is also not reported from other regions of India (Garg, 1988). Therefore, G. paludosa var. alpina is reported here for the first time in India, from the Trans-Himalayan region of Ladakh.

\section{Materials and Methods}

Standard methods were used for collection, processing and preparation of the herbarium specimens (Bridson \& Forman, 1998). Voucher specimens have been deposited at the University of Kashmir Herbarium (KASH). Identification was carried out by consulting Gentianaceae in the Flora of China (Ho \& Pringle, 1995). The micromorphological characters were analysed and photographed using a trinocular S9D stereo microscope integrated with 10 MP CMOS-camera and LASX image processing software (Leica, Wetzlar, Germany). The geo-coordinates were recorded with an eTrex 30x global positioning system (Garmin, New Taipei City, Taiwan). 


\section{Taxonomic Treatment}

Gentianopsis paludosa (Hook.f.) Ma var. alpina T.N.Ho, Acta Biol. Plateau Sin. 1: 41. 1982. Type: CHINA, Qinghai, Jiuzhi Xian, Alt. 3820 m, 23.07.1971, Qinghai Inst. Biol. Golog. Exped. 313 (holo NWBI!) Fig. 1

Annual herbs, 3-40 cm tall. Stems erect, branched from the base. Leaves dimorphic; basal leaves 3-5 pairs, petiolate, petioles angled, $1.5-3 \mathrm{~cm}$ long, lamina spathulate, $0.5-4 \times 0.5-1.5 \mathrm{~cm}$, base cuneate, margins scabrous, leaf tip rounded; cauline leaves 1-4 pairs, opposite, sessile, 0.5-6.0 $\times 0.5-1.9 \mathrm{~cm}$, lamina oblong to elliptic-lanceolate, base obtuse, margins scabrous, leaf tip obtuse, 1-3-veined. Flowers solitary, axillary and terminal, 5-20 per plant, bisexual, 3-6 cm long; pedicels 1.5$20 \mathrm{~cm}$ long, light green to creamy white. Calyx 1-3.5 cm long, 4-lobed; lobes unequal with membranous margins, outer lobes prominently triangular, inner lobes ovate, apex acuteacuminate, midvein of the lobe strong and conspicuously keeled. Petals 4, white to creamy yellow, tubular, corolla tube $1.5-3.5 \mathrm{~cm}$ long; lobes oblong, $1.5-2.5 \mathrm{~cm}$ long, apex roundedtruncate, free end of the lobes proximally fringed. Stamens 4, introrse, epipetalous; filament length $1-3.5 \mathrm{~cm}, 2.5 \mathrm{~cm}$ basally attached to the corolla tube and $0.5-1.5 \mathrm{~cm}$ free, white-transparent; anthers versatile, $2-3 \mathrm{~mm}$ in length. Nectaries 4 , alternate with stamens, 4-6 $\mathrm{mm}$ above the base of corolla, suborbicular. Ovary monocarpellary, fusiform, 1.5-3.5 cm; style 1-1.4 mm long; stigma bi-lobed, semiorbicular, 1-1.3 × 1-1.6 mm. Capsule ellipsoid with tapering ends, $2-6.5 \mathrm{~cm} \times$ 2-4 mm. Seeds ovoid to lanceoloid-ellipsoid, 0.5-1.5 × 0.3-0.6 mm, golden-brown .

Flowering \& fruiting: Flowering from June to July and fruiting from August to September.

Habitat: Mountain stream banks, alpine meadows, moist mountain slopes.
Distribution: China, now also in India; between 3100 to $4000 \mathrm{~m}$ altitude (Fig. 2).

Specimens examined: INDIA, Ladakh, Kargil district, Bhimbat, N 34²6'50.59", E 7549'34.12", 3191 m, 05.09.2020, S. Banoo, A.A. Khuroo \& A.H. Ganie 45253; Gindial, N 34²5'50.17", E 7550'57.52", 3197 m, 17.07.2019, S. Banoo, A.A. Khuroo \& A.H. Ganie 45045; Goshan, N 34²6'38.75", E 75 44'49.82", 3219 m, 29.07.2020, S. Banoo, A.A. Khuroo \& A.H. Ganie 45046; Matayen, N 34 21'57.76", E 75³5'22.19", 3285 m, 13.06.2019, S. Banoo, A.A. Khuroo E A.H. Ganie 45047; Mushkoo, N 34²6'16.31", E 75 39'48.71", 3205 m, 17.07.2020, S. Banoo, A.A. Khuroo \& A.H. Ganie 45044; Pandrass, N 34 24'50.92", E 75³7'55.77", $3221 \mathrm{~m}, 12.07 .2019$, S. Banoo, A.A. Khuroo \& A.H. Ganie 45048 (KASH).

Notes: Gentianopsis paludosa var. alpina can be distinguished from var. paludosa by many morphological characters. In the former the plants have 5-20 flowers, the corolla is white to creamy yellow, the pedicel light green to cream coloured and the branches arise from the base, whereas in the latter variety the plants are 1 or 2-flowered, the corolla blue, the pedicel brown-coloured and the branches arise much above the base (Fig. 3, Table 1).

The species, Gentianopsis paludosa is commonly known as "shi sheng bian lei" in China, and has been reported to be used for the treatment of conjunctivitis, hypertension, haemorrhoids, hepatitis, nephritis, gastroenteritis, dyspepsia, fever, influenza, and diarrhoea (Guo, 1987; Xue \& Li, 2011). Phytochemical studies have shown that it contains xanthones, terpenoids and flavonoids (Zhang et al., 1980; Wang et al., 2004, 2006). The present distribution record of G. paludosa var. alpina from the remote mountainous region of Ladakh in India expands its range, and the variety merits further research to investigate its potential phytochemical constituents and pharmacological applications. During the present study, it was observed that the plant is locally consumed as a wild vegetable 

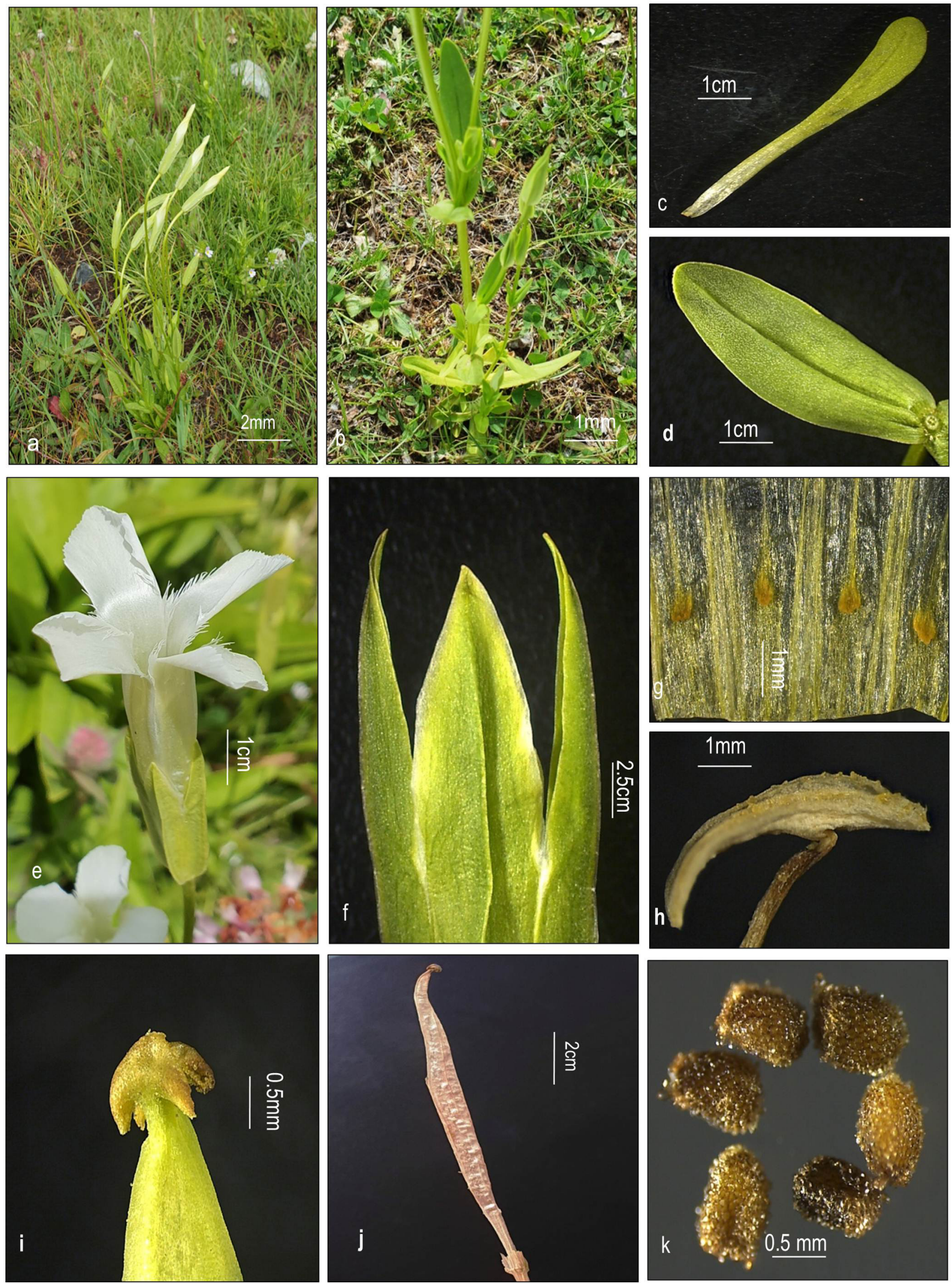

Fig. 1. Gentianopsis paludosa (Hook.f.) Ma var. alpina T.N.Ho: a. Habit; b. Habit showing branching from the base; c. Basal leaf; d. Cauline leaf; e. Flower; f. Calyx lobes showing membranous margins; g. Nectaries alternating with stamens; h. Anther; i. Carpel with short style and lobed stigma; j. Fruit; k. Seeds (from S. Banoo, A.A. Khuroo \& A.H. Ganie 45044; photos by S. Banoo). 


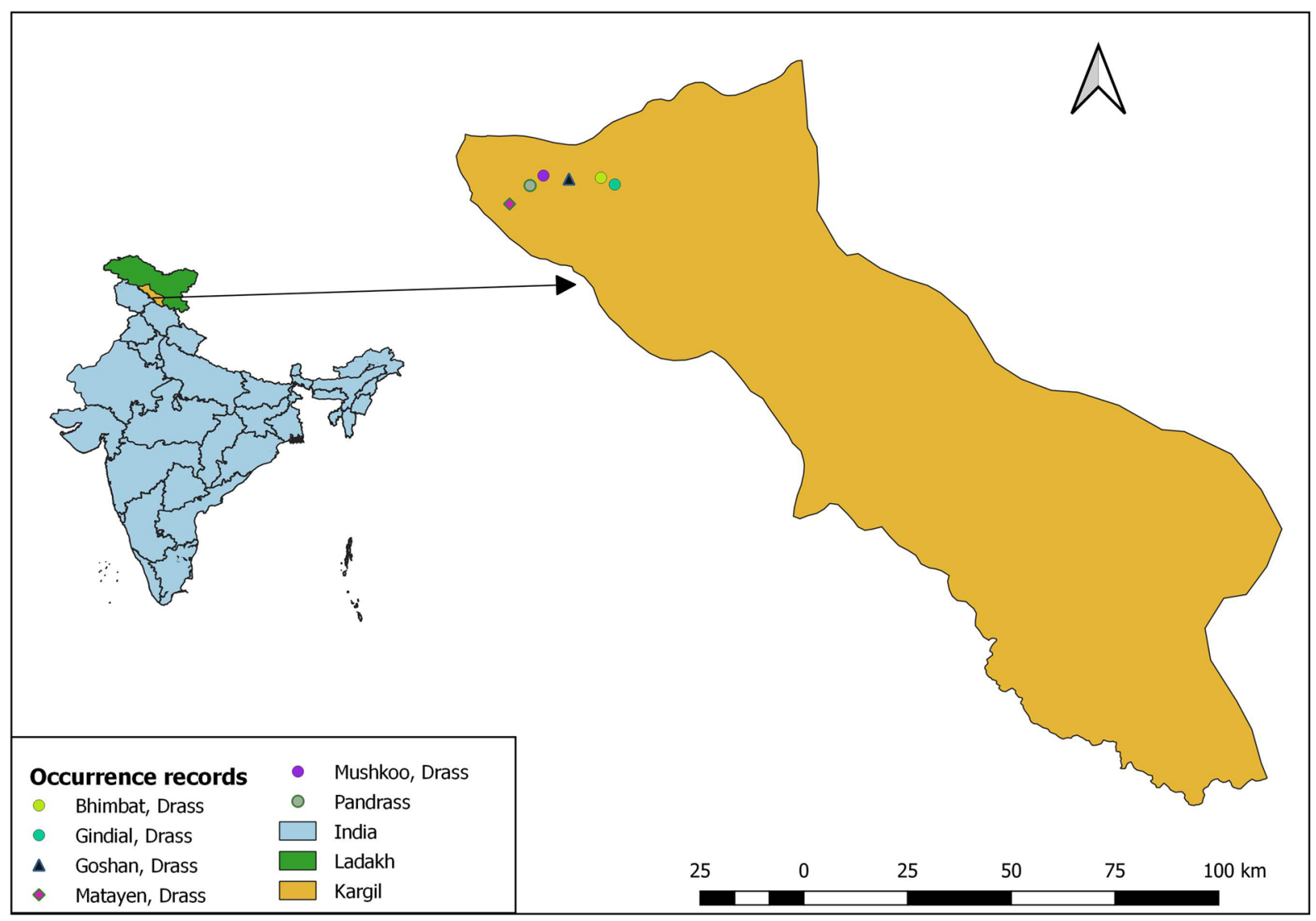

Fig. 2. Map of the study area and collection localities of Gentianopsis paludosa (Hook.f.) Ma var. alpina T.N.Ho in Ladakh (QGIS Version 3.18, 2020).

during the early vegetative stage. Furthermore, it has been observed that this taxon shows a restricted distribution and occurs only in a few localities in relatively small populations. However, its conservation status in India needs further detailed population level studies at much larger spatial scale across the region.

\section{Acknowledgements}

The research students and supporting staff at BIOTA Laboratory at Centre for Biodiversity \& Taxonomy, Department of Botany, University of Kashmir are acknowledged for their kind help during the course of present study. First author,

Table 1. Comparison of diagnostic characters between Gentianopsis paludosa var. alpina and G. paludosa var. paludosa

\begin{tabular}{|l|l|l|}
\hline Diagnostic characters & $\begin{array}{l}\text { G. paludosa (Hook.f.) Ma var. } \\
\text { alpina T.N.Ho }\end{array}$ & G. paludosa (Hook.f.) Ma var. paludosa \\
\hline Stem & Branched from the base & Branched much above the base \\
\hline $\begin{array}{l}\text { No. of flowers per } \\
\text { plant }\end{array}$ & $5-20$ & 1 or 2 \\
\hline Corolla & Whitish to creamy yellow & Bright blue, sometimes pale yellow at base \\
\hline Pedicels & $\begin{array}{l}1.5-20 \mathrm{~cm} \text { long, light green to } \\
\text { creamy white }\end{array}$ & $2-12 \mathrm{~cm}$ long, brown \\
\hline
\end{tabular}



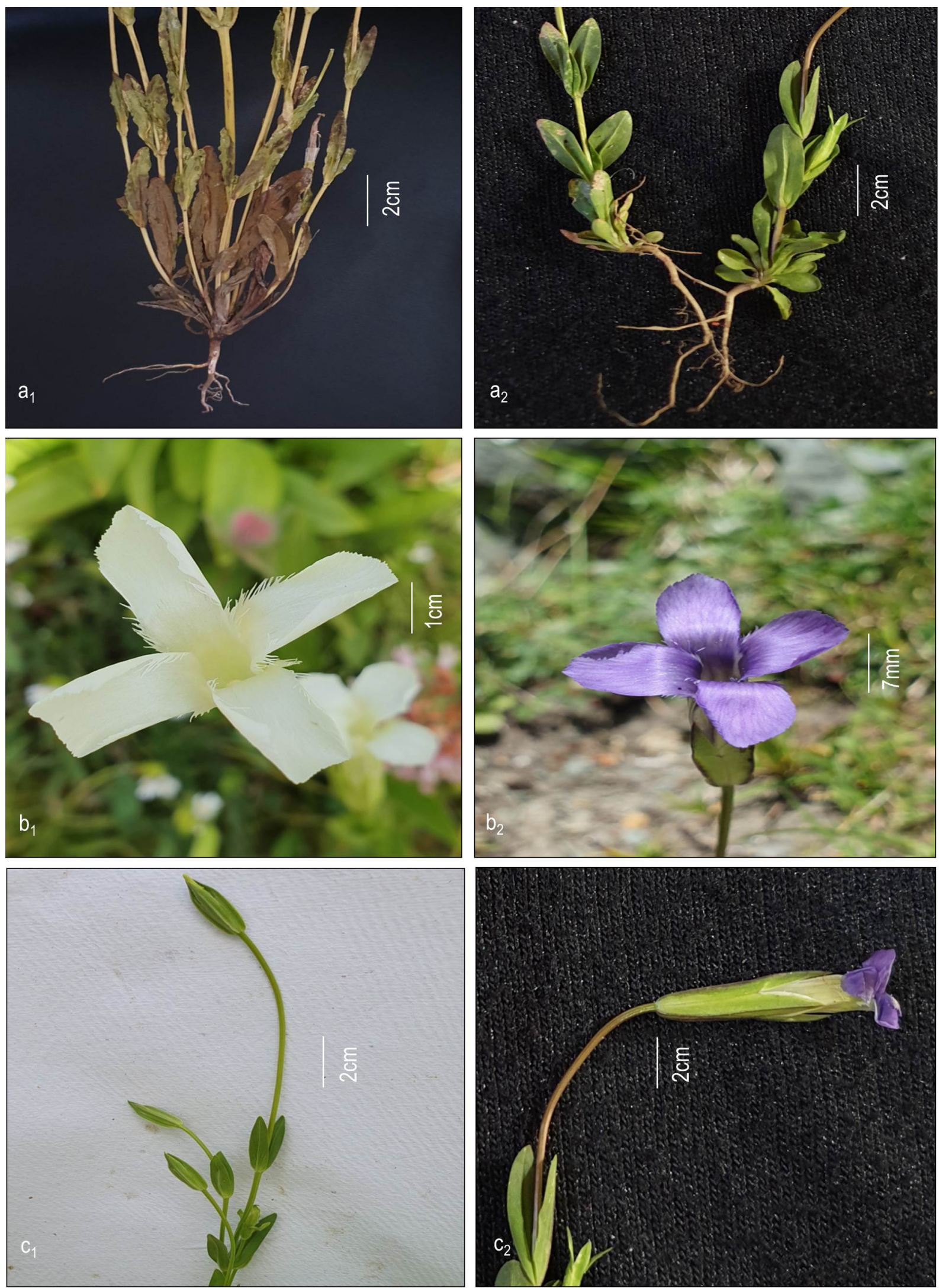

Fig. 3. Comparison of diagnostic characters of Gentianopsis paludosa (Hook.f.) var. alpina T.N.Ho (a - c c $_{1}$ and G. paludosa (Hook.f.) var. paludosa $\left(\mathbf{a}_{2}-\mathbf{c}_{2}\right)$ : a. Stem branching; b. Corolla; c. Pedicel ( $\mathrm{a}_{1}-\mathrm{C}_{1}$ from S. Banoo, A.A. Khuroo \& A.H. Ganie 45044, and $\mathrm{a}_{2}-\mathrm{C}_{2}$ from S. Banoo, A.A. Khuroo \& A. H. Ganie 45054; photos by S. Banoo). 
Sakina Banoo acknowledges financial support as junior research fellow provided by the University Grants Commission, New Delhi, during the present study. Senior author, Anzar A. Khuroo, acknowledges financial support by Ministry of Environment, Forest \& Climate Change (MoEFCC), Govt of India, New Delhi, India, under AICOPTAX project (F. No.22018/12/2015/ $\mathrm{RE}(\mathrm{Tax})$. We are highly thankful to Dr Gao Tiangang, Institute of Botany, Chinese Academy of Sciences, Beijing, China for sharing the type information. We are grateful to the anonymous reviewers and Executive Editor, Rheedea, for critical comments and suggestions on the manuscript which improved its quality.

\section{Literature Cited}

BRIDSON D. \& L. FORMAN 1998. The herbarium handbook. Royal Botanic Gardens, Kew.

CHAURASIA O.P., KHATOON N. \& S.B. SINGH 2008. Field guide to floral diversity of Ladakh. Field Research Laboratory, Defence Research and Development Organization, Leh, Ladakh.

DAR G.H. \& A.A. KHUROO 2020. An updated taxonomic checklist of angiosperms in Jammu and Kashmir state. In: DAR G.H. \& A.A. KHUROO (eds.), Biodiversity of the Himalaya: Jammu and Kashmir State. Springer, Singapore. pp. 467-519.

DVORSKY M., KLIMES L., DOLEZAL J., WILD J. \& B.W. DICKORE 2018. A field guide to the Flora of Ladakh. Academia, Praha.

GARG S. 1988. Indian Gentianaceae: a check-list. Northern Book Centre, New Delhi.

GUO B.Z. 1987. Medicinal plants of Qinghai province. Qinghai People's Publishing House, Xining.

GURMET P. 2004. "Sowa-Rigpa": Himalayan art of healing. Indian Journal of Traditional Knowledge 3(2): 212-218.

HO T.N. \& J.S. PRINGLE 1995. Gentianaceae. In: WU Z.Y. \& P.H.RAVEN (eds.), Flora of China. Volume 18.
Science Press, Beijing, \& Missouri Botanical Garden Press, St. Louis. pp.1-139.

ILTIS H.H. 1965. The genus Gentianopsis (Gentianaceae): transfers and phytogeographic comments. Sida, Contributions to Botany 2(2): 129-153.

KALA, C.P. 2011. Floral diversity and distribution in the high altitude cold desert of Ladakh, India. Journal of Sustainable Forestry 30(5): 360-369. https://doi.org/ 10.1080/10549811.2011.534036

MA Y.C. 1951. Gentianopsis - a new genus of Chinese Gentianaceae. Journal of Systematics and Evolution 1(1): 5-9. https://www.jse.ac.cn/EN/Y1951/V1/I1/5

POWO 2019. Plants of the World Online. Facilitated by the Royal Botanic Gardens, Kew. Available at: http:// www.plantsoftheworldonline.org/ (Accessed on 17.11.2020).

PRINGLE J.S. 2014. Morphological characteristics of the family Gentianaceae. In: RYBCZYNSKI J., DAVEY M. \& A. MIKULA (eds.), The Gentianaceae - Volume 1: Characterization and Ecology. Springer, Berlin.pp. 1-12. https://doi.org/10.1007/978-3-642-54010-3_1

QGIS Version 3.18. 2020. Geographic Information System. Open Source Geospatial Foundation Project. Available at: http://qgis.osgeo.org/ (Accessed on 10.11.2020).

WANG H.D., TAN C.Y., DU Y.G., BAI X.F. \& H.F. LU 2004. Study on the chemical constituents from the herb of Gentianopsis paludosa. China Journal of Chinese Materia Medica 29(11): 1055-1056.

WANG H.D., TAN C.Y., BAI X.F., DU Y.G. \& B.C. LIN 2006. Pharmacological studies of anti-diarrhoeal activity of Gentianopsis paludosa. Journal of Ethnopharmacology 105(1-2): 114-117. https://doi.org/10.1016/ j.jep.2005.10.002

XUE C.Y. \& D.Z. LI 2011. Use of DNA barcode sensu lato to identify traditional Tibetan medicinal plant Gentianopsis paludosa (Gentianaceae). Journal of Systematics and Evolution 49(3): 267-270. https://doi.org/ 10.1111/j.1759-6831.2011.00127.x

ZHANG B.C., ZHEN R.D. \& B.L. HU 1980. Study on the chemical constituents from Gentianopsis paludosa. Chinese Traditional and Herbal Drugs 11(4): 149-151. 